\title{
Bucolome in prevention of hyperbilirubinaemia in preterm infants
}

\author{
G. SEGNI, G. POLIDORI, and C. ROMAGNOLI \\ From Clinica Pediatrica, Università Cattolica del Sacro Cuore, Rome, Italy
}

SUMMARY Fifty preterm babies were randomly assigned to a group given oral bucolome $(30 \mathrm{mg} / \mathrm{kg}$ per day for 5 days) and a control group. Serum bilirubin levels of the treated infants from day 4 onwards were consistently lower than those of the control infants. 3 of the 25 control infants (but none of the 25 treated infants) had bilirubin levels $>18 \mathrm{mg} / 100 \mathrm{ml}(308 \mu \mathrm{mol} / \mathrm{l})$ and required exchange transfusion. No sedation or drowsiness was observed in the infants given bucolome, and though the drug caused some vomiting, weight gains were unaffected.

A barbituric product, 1-cyclohexyl-5n-barbituric acid (bucolome) has been claimed by workers in Japan to lower serum bilirubin by a mechanism similar to that of phenobarbitone, but without the latter's hypnotic effect (Fujimura et al., 1967; Yamamoto and Sakamoto, 1971; Baba, 1972/73; Romagnoli et al., 1975). We report results obtained using bucolome in prevention of hyperbilirubinaemia in preterm infants.

\section{Materials and methods}

Fifty preterm newborn infants, of gestational age 33-36 weeks, were randomly assigned to a treated group and a control group (Table 1). Infants with

Table I Clinical characteristics of treated and control groups

\begin{tabular}{|c|c|c|}
\hline & $\begin{array}{l}\text { Controls } \\
n=25\end{array}$ & $\begin{array}{l}\text { Treated } \\
n=25\end{array}$ \\
\hline $\begin{array}{l}\text { Sex }(M: F) \\
\text { Gestational age }(w) \\
(\text { mean } \pm \text { SE })\end{array}$ & $\begin{array}{l}9: 16 \\
34 \cdot 4( \pm 0 \cdot 4)\end{array}$ & $\begin{array}{c}7: 18 \\
34 \cdot 4( \pm 0 \cdot 4)\end{array}$ \\
\hline $\begin{array}{c}\text { Birthweight (g) } \\
\text { (mean } \pm \text { SE) }\end{array}$ & $2074( \pm 63)$ & $2066( \pm 60)$ \\
\hline $\begin{array}{l}\text { Haematocrit }(\%) \\
(\text { mean } \pm \text { SE) }\end{array}$ & $60 \cdot 8( \pm 1)$ & $60 \cdot 5( \pm 2)$ \\
\hline $\begin{array}{l}\text { Meconium passage (h) } \\
\text { (mean } \pm \text { SE) }\end{array}$ & $11 \cdot 2( \pm 2)$ & $12( \pm 3)$ \\
\hline
\end{tabular}

haemolytic anaemia, neonatal asphyxia, respiratory distress syndrome, sepsis, or malformation were excluded from the study. Infants whose mothers

Received 8 November 1976 had received any treatment such as phenobarbitone or cortisone which might influence the neonatal hyperbilirubinaemia were also excluded.

Blood group, Rh factor, Coombs's test, Hb, RBC, WBC, and reticulocyte counts, haematocrit, blood glucose, plasma electrolytes, acid-base status, chest $x$-ray, and cultures were recorded for each baby in the first 12 hours of life and at the end of treatment. Total serum bilirubin (Malloy and Evelyn, 1937) was measured on admission (always before starting treatment) and afterwards at 9 am every day for 7 days, conjugated bilirubin on alternate days. The acid-base status, blood glucose, plasma electrolytes, and haematocrit were checked daily.

Feeds were begun when the infant was 6 hours old. Infants with hypoglycaemia ( 5 of the treated babies and 4 of the control babies) received glucose solution intravenously.

The newborn infants of the treated group received bucolome (Bucolome Savio, $2 \%$ ) orally $30 \mathrm{mg} / \mathrm{kg}$ per day in two divided doses starting with the first milk feed and continuing for 5 days; it was given by nasogastric tube. Control infants received no treatment for hyperbilirubinaemia, except for exchange transfusion given in accordance with the policy of Blumenschein et al. (1968). The behaviour, motor activity, feeding, respiration, and reflexes of all infants were observed daily.

\section{Results}

None of the 25 treated infants showed lack of sucking, apnoeic spells, or drowsiness, but 10 of them showed a tendency to vomit some time after administration of the drug. Weight gains were 
similar in both groups: $33 \%$ of treated infants and $23 \%$ of control infants gained weight. The Fig. shows the serum bilirubin during the first week of life for the two groups. Values remained the same for the two groups for days 1-3, but thereafter were significantly lower in the treated group. The variance analysis by factorial design $(2 \times n)$ showed that serum bilirubin of the treated infants diminished significantly $(P<0.0001)$ and more rapidly $(P<0.0001)$ than in the control infants. Table 2 shows the

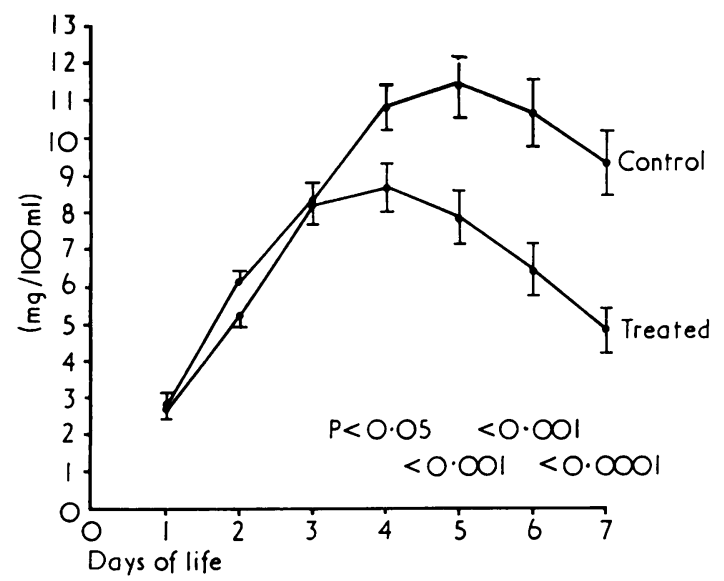

Fig. Daily total serum bilirubin of study groups (mean $\pm S E$ ). Conversion: Traditional units to SIBilirubin: $1 \mathrm{mg} / 100 \mathrm{ml} \approx 17 \cdot 1 \mu \mathrm{mol} / \mathrm{l}$.

Table 2 Number and percentage of babies whose serum bilirubin levels exceeded 12, 15, and $18 \mathrm{mg} / 100 \mathrm{ml}$ and of babies who received exchange transfusions

\begin{tabular}{|c|c|c|c|c|}
\hline & \multicolumn{4}{|c|}{$\begin{array}{l}\text { Serum bilirubin } \\
(\mathrm{mg} / 100 \mathrm{ml})\end{array}$} \\
\hline & $>12$ & $>15$ & $>18$ & $\begin{array}{l}\text { Exchange } \\
\text { transfusions }\end{array}$ \\
\hline $\begin{array}{l}\text { No. treated } \\
\text { No. of controls }\end{array}$ & $\begin{array}{r}4(16 \%) \\
13(52 \%)\end{array}$ & $\begin{array}{l}1(4 \%) \\
8(32 \%)\end{array}$ & $\begin{array}{l}0 \\
3 \text { (12\%) }\end{array}$ & $\begin{array}{l}0 \\
3 \text { (12\%) }\end{array}$ \\
\hline
\end{tabular}

*See legend to Fig. for conversion from traditional units to SI.

number of infants in whom bilirubin levels exceeded 12,15 , and $18 \mathrm{mg} / 100 \mathrm{ml}(205,257,308 \mu \mathrm{mol} / \mathrm{l})$, and the number who required exchange transfusions.

\section{Discussion}

Our results show that administration of bucolome substantially reduces the hyperbilirubinaemia of the preterm newborn infants, in agreement with Baba's (1972/73) experience in term newborn infants. We observed no sedative effect of the drug at the dosage of $30 \mathrm{mg} / \mathrm{kg}$ per day. In 6 other infants who were given $60 \mathrm{mg} / \mathrm{kg}$ per day for 3 days no drowsiness was observed, but there was moderate vomiting.

Our observations now lead us to use bucolome in the prevention of preterm hyperbilirubinaemia (Centa et al., 1976; Gavinelli et al., 1976). There is a need to try different schedules, dosage, or ways of administering the drug in exploring its use in the treatment of hyperbilirubinaemia so as to avoid its tendency to induce vomiting.

We thank Prof. Renato Mastrangelo for helpful discussion; Dr. M. Cagossi for statistical analysis; and the nursing staff of the Premature Infants Centre for their support.

\section{References}

Baba, K. (1972/73). Use of bucolome in hyperbilirubinaemia. Pediatrician, 1, 109-111.

Blumenschein, S., Kallen, R., Stoney, B., Natzschka, C., Odell, G. B., and Childs, B. (1968). Familial nonhemolytic jaundice with late onset of neurological damage. Pediatrics, 42, 786-792.

Centa, A., Camera, G., Piccinini, A., Di Pietro, P., and Tomatis, C. (1976). Impiego di 5-butil-1-cicloesil-2,4,6trioxiperidropirimidina (BCP) nella profilassi e nella terapia dell'iperbilirubinemia neonatale. Minerva Pediatrica, 28, 911-921.

Fujimura, H., Tsurumi, A., and Hayashi, M. (1967). Pharmacological study on 5n-butyl-1-cyclohexyl-2,4,6trioxoperhydropyrimidine as an anti-inflammatory drug. Folia Pharmacologica Japonica, 63, 43-86.

Gavinelli, R., Gallenca, M., and Grasso, G. P. (1976). L'acido 1-cicloesil-5-butil barbiturico nel trattamento delle iperbilirubinemia neonatali. Minerva Pediatrica, 28, 922-931.

Malloy, H. T., and Evelyn, K. A. (1937). The determination of bilirubin with the photoelectric colorimeter. Journal of Biological Chemistry, 119, 481-490.

Romagnoli, C., Cataldi, L., and Polidori, G. (1975). Orally administered phenobarbital in the prophylaxis of non haemolytic jaundice of low birth-weight newborns. Acta Medica Romana, 13, 23-30.

Yamamoto, T., and Sakamoto, K. (1971). Treatment of constitutional hyperbilirubinaemia. Acta Hepatica Japonica, 12, 173-175.

Correspondence to Dr. C. Romagnoli, Clinica Pediatrica, Università Cattolica del S. Cuore, Largo A. Gemelli 8, 00168 Roma, Italy. 